\section{Palliative care in paediatric oncology: perceptions, expertise and practices from the perspective of the multidisciplinary team}

\author{
Cuidados paliativos em oncologia pediátrica: percepções, saberes \\ e práticas na perspectiva da equipe multiprofissional
}

Cuidados paliativos en oncología pediátrica: percepciones, saberes

y prácticas bajo la perspectiva de un equipo multidisciplinario

\author{
Adriana Ferreira da Silva ${ }^{a}$ \\ Helena Becker Issib \\ Maria da Graça Corso da Mottac \\ Daisy Zanchi de Abreu Botene ${ }^{\mathrm{d}}$
}

\begin{abstract}
Objective: To reveal the perceptions, expertise and practices of multi-professional teams providing palliative care to children in a paediatric oncology unit. The research questions were based on everyday care, facilitations and difficulties, essential aspects of professional approaches, and the inter-disciplinary focus of care for children in palliative care and their families.

Method: Qualitative, exploratory and descriptive research. Data were collected from June to October 2013 from nine professional multidisciplinary team members by means of a semi-structured interview submitted to thematic analysis.

Results: The following four themes emerged from analysis: palliative care: conceptions of the multi-professional team; the construction of singular care; the facilitations and difficulties experienced by the team and significant lessons learned.

Conclusions: The subjects revealed that the team also suffers with the death of a child and, like the family, moves toward the construction of coping mechanisms for the elaboration of mourning. Paradoxically, the team shares knowledge to determine the foundations of a singular therapeutic project and inserts the family in this process so that it can be the protagonist of the child's care. Keywords: Palliative care. Oncology. Paediatrics. Patient care team.
\end{abstract}

\section{RESUMO}

Objetivos: Conhecer as percepções, saberes e práticas da equipe multiprofissional na atenção às crianças em cuidados paliativos em unidade de oncologia pediátrica. As questões norteadoras basearam-se no cotidiano do cuidado, nas facilidades e nas dificuldades vivenciadas, aspectos essenciais da abordagem profissional, e no enfoque interdisciplinar na atenção às crianças em cuidados paliativos e suas famílias. Método: Pesquisa qualitativa, exploratória e descritiva. Os dados foram coletados de junho a outubro de 2013 junto a nove profissionais integrantes da equipe multidisciplinar por meio de entrevista semiestruturada e submetidos à análise temática.

Resultados: Da análise emergiram quatro temas intitulados cuidados paliativos: concepções da equipe multiprofissional; a construção de um cuidado singular; as facilidades e as dificuldades vivenciadas pela equipe e aprendizagens significativas.

Conclusões: Os temas revelaram que a equipe sofre, igualmente, com a morte da criança e, de forma semelhante à família, move-se em direção à construção de mecanismos de enfrentamento para a elaboração do luto. Paradoxalmente, a equipe compartilha saberes para delinear as bases do projeto terapêutico singular a ser implementado e insere a família nesse processo para que possa assumir o protagonismo do cuidado à criança. Palavras-chave: Cuidados paliativos. Oncologia. Pediatria. Equipe de assistência ao paciente.

\section{RESUMEN}

Objetivos: Conocer las percepciones, saberes y prácticas de un equipo multidisciplinario en la atención a niños bajo cuidados paliativos en una unidad de oncología pediátrica. Las preguntas orientadoras se basaron en el cuidado diario, las facilidades y las dificultades, aspectos esenciales del enfoque profesional, y el enfoque interdisciplinario en el cuidado de los niños en cuidados paliativos y sus familias.

Método: Se trata de un estudio cualitativo, exploratorio y descriptivo. La recopilación de los datos se realizó de junio a octubre de 2013 junto a nueve profesionales que integran un equipo multidisciplinario por medio de entrevista semiestructurada y sometidos al análisis temático.

Resultados: Del análisis cuatro temas emergieron: cuidados paliativos: concepciones del equipo multidisciplinario; la construcción de un cuidado singular; las facilidades y las dificultades vividas por el equipo y aprendizajes significativos.

Conclusiones: Estos temas revelaron que el equipo también sufre con la muerte del niño y, del mismo modo que la familia, se mueve hacia la construcción de mecanismos de enfrentamiento para la elaboración del luto. Paradójicamente, el equipo comparte saberes para delinear las bases del proyecto terapéutico a ser implementado e inserta la familia en ese proceso para que ella pueda asumir el protagonismo del cuidado al niño. Palabras clave: Cuidados paliativos. Oncología médica. Pediatría. Grupo de atención al paciente.
D0l: http://dx.doi.org/10.1590/1983-

1447.2015.02.46299

\footnotetext{
Nurse of the TMO Protected Environment Unit at the Hospital de Clínicas de Porto Alegre (HCPA). Specialist in Oncology and Hematology from the Multidisciplinary Integrated Residency in Health HCPA.

${ }^{b}$ Enfermeira. Master of Education. PhD student of the Graduate Programme in Nursing at the School of Nursing of the Universidade Federal do Rio Grande do Sul (EEUFRGS). Professor of the Department of Maternal Nursing of the EEUFRGS.

c Enfermeira. Doctor of Nursing Practice. Associate Professor of the Department of Maternal/Child Nursing of the EEUFRGS.

d Enfermeira. Doctor of Nursing Practice. Professor at the Centro Universitário Metodista - IPA
} 


\section{DINTRODUCTION}

The treatment of childhood cancer is lengthy and the everyday interaction of health care professionals with the children and their families forces these professionals to experience the expectations of treatment and truly suffer when all possibilities of a cure are exhausted. In paediatrics, palliative care is often provided to children with severely life-limiting conditions, especially those who are approaching the end of their lives. However, many children in life-threatening chronic conditions could benefit from this model of care during the entire trajectory of the disease ${ }^{(1)}$.

Paediatric palliative care is characterized as "active and total assistance for the body, mind and spirit of the child, and the provision of family support, including during the period of mourning ${ }^{\prime \prime 2}$. With the advancement of medicine, death stopped occurring at the homes of patients and started to occur at the hospital ${ }^{(1,3)}$. Thus, the death of a child in palliative care often occurs in the hospital environment, and the team that was previously fully dedicated to curing the illness, must now face the end of life and the family's pain. This event demands both technical and scientific knowledge and considerable emotional preparation to assist families facing this final moment ${ }^{(1,4)}$.

The education of health care professionals is predominantly based on a biologic approach to patient care $^{(5)}$, in which the body is seen as a machine and is considered the only object of intervention. However, paediatric oncology seeks a broader view on the subject of care through the continuous debate of reflection on its praxis and the understanding that"knowledge helps, but this alone does not solve anyone's problems. If you don't use your head, your heart and your soul, you will not be able to help a single human being"(6). Respect for the individuality and value of human beings in their entirety is the primordial quality that guides professionals in this area toward the practice of ethical, aesthetic and humanized care ${ }^{(7)}$.

The complexity of this subject and the scarcity of literature and research justify the realization of this study. Consequently, the aim of this paper is to understand the perceptions, expertise and practices of multidisciplinary teams that provide palliative care for children at a paediatric oncology unit. A framework that reveals a compassionate and genuine view of children and the families that experience this process was used to support this objective ${ }^{(1,4,6)}$.

\section{METHODOLOGY}

This study is based on a qualitative, exploratory and descriptive research method. The study was conducted at a teaching hospital in southern Brazil. It was submitted to Plataforma Brasil and approved by the Research Ethics Committee of the institution, under number 13-0077.

Study participants consisted of nine professionals of a multidisciplinary team. Each member of the team represented a specific profession, namely a physician, a nurse, a nursing technician, a social worker, a psychologist, a physical educator, an educator, a nutritionist, and a pharmacist. Inclusion criteria were a minimum of one year of professional experience and currently providing palliative care for children. The professionals were randomly drawn, given that each profession had at least two representatives. After they accepted to participate in the study, each member signed an informed consent statement.

Data were collected from June to October 2013 by means of a previously scheduled semi-structured interview conducted after the participant's work day, in a room provided by the Research and Post-Graduate Studies Group of the institution. The research questions were based on everyday care routines, facilitations and difficulties, the essential aspects of professional approaches, and the inter-disciplinary focus of care for children in palliative care and their families.

The collected data were subjected to thematic content analysis ${ }^{(8)}$ divided into three steps: a) pre-analysis; b) exploration of the material; and c) treatment and interpretation of the results. This analysis resulted in four themes: palliative care: conceptions of the multi-professional team; the construction of singular care; the facilitations and difficulties experienced by the team and significant lessons learned.

To maintain the reliability of the statements, the interviews were recorded and transcribed in full, and the names of the participants were replaced by the letter "S" followed by numbers. Guidelines for research with human beings were observed, in accordance with Resolution 466/2012 of the National Health Counci('(9).

\section{RESULTS AND DISCUSSION}

The manner in which the multidisciplinary team viewed the experiences of children in palliative care and their families is revealed in the following titles.

\section{Palliative Care: conceptions of the multidisciplinary team}

The statements of participants regarding their perceptions of palliative care revealed the personal construction of an improved concept during their daily practices: 
It's mostly the act of caring in and of itself! It's being able to provide everything that person and their family needs, regardless of whether you are focusing on the prospect of an approaching death. It is providing care in relation to pain, being comfortable with their loved ones and of receiving more visitations. So, that's what palliative care is: focusing on care. It's valuing the process and act of care (S5).

This statement reveals that when care superimposes the cure, health workers feel the need to reconsider their role during this delicate moment in the lives of a family, and understand that the main goal is to regain the humanization that was lost during the health care actions ${ }^{(5)}$.

Treatment for cancer is considered a battle in the struggle against death. At this point, when a cure is no longer part of the prognosis, health workers feel that medicine has failed their patient, resulting in feelings of impotence, depression and denial ${ }^{(1,10)}$. This leads to the emergence of philosophical and existential questions that are inherent to the perspective of an early death, where social death precedes biological death and increases the suffering of all the persons involved in the provided care $^{(5)}$. There is also a deconstruction of the social image of the child, which goes against the natural order of life cycles.

It goes against the natural laws of life: they are children and this is the inverse process. That's why we are so shaken (59).

I've thought about not working with children or oncology anymore, because it's not normal you see children die. It's totally unnatural. But, we also have to follow the other path and that's when I see just how important our work is to them [...], it makes my work so gratifying that I forget about the other aspect of it (S3).

Health workers who work in the field of paediatric oncology "are initially confronted with a major shift in their focus of attention. Although they are trained to deal with the concept of health, they must now work with the concept of a progressing disease. The much-desired cure is slowly replaced by improving the patient's quality of life ${ }^{\prime \prime(1,11)}$. Consequently, the same team that suffers the ambivalence of their professional praxis also manages to understand the importance of its role at these difficult moments, and feels gratified when it is able to ensure some dignity for the children until the moment of death.

\section{The construction of singular care}

Due to the characteristics of the disease and treatment of paediatric cancer, physical pain is an expected phenomenon.

All palliative care is singular [..., pain is something predictable. You have to find ways to minimize physical pain, but you can't measure or apply protocols to treat the emotional pain, the pain of an imminent death, the pain of saying goodbye (S1).

The statement reveals the existence of a more complex pain that is understood as absolute pain ${ }^{(12)}$. This concept reveals that the patient's pain is not only related to the pathology; it includes physical, emotional and spiritual aspects. It is the loss of the status of being healthy. At this stage, the team tries to provide care to the child in its entirety ${ }^{(13)}$.

In addition to having the capacity to understand and act on the child's absolute pain, it must learn to cope with the pain of the family. This forces the team to articulate its knowledge and establish a singular therapeutic model based on a set of proposals and therapeutic conducts that can help it understand the singularity of each patient and define effective proposals and actions ${ }^{(14)}$.

We discuss this as a team. It's a calm process, because the team can understand the needs of both the family and the child and can establish this model. That's how it works, it's a joint project (56).

The health care professionals include the families in this proposal and value their co-responsibility, which encourages the family members to be the protagonists of the child's care.

We know that decisions at this point have to be further discussed among the professionals and must also involve the family. Our way of working here is always talking about everything openly, but this also requires the sensitivity of knowing if it's the right time and if the person is ready to hear what you have to say (S4).

The collective construction of a therapeutic plan enhances communication, respect and interpersonal relationships, which represents the essence of a care that sustains faith and hope at the most difficult moments ${ }^{(6,14)}$. At these moments, the team grants exceptions to otherwise strict rules to ensure the child is comforted and treated with affection. 
Feeding involves pleasure, wellness, affection and care. We opens exceptions with the mothers at the most terminal stage because not eating bothers the mothers rather than the children (S4).

There are some things that we can't do: If the patient has a venturi mask, I know it won't help to saturate this patient. I'll only make the family more anxious if I check something I can't change (S2).

Understanding these peculiarities is part of the team's everyday routine. And the team provides the support at this moment of uncertainty and suffering. It should be noted that human beings essentially require care and the assurance that their needs will be met so that they can live a full life until the end and have a dignified death ${ }^{(13)}$.

\section{The facilitations and difficulties experienced by the team}

When questioned as to the facilitations and difficulties in providing palliative care to children and their families, the health care professionals revealed that this topic was rarely discussed during their education.

I've realized that we start attending people without a solid basis for that type of care. We come in here to look after these children without having any prior experience and we have to learn a lot of things on our own (S6).

Death, when addressed in academia, is limited to something that is strictly biological. The disruptions and changes involved in the process of dying are still scarcely discussed ${ }^{(5)}$. The less-experienced professionals seek to exchange information with their colleagues and subsequently create a rich moment of knowledge construction.

I got some really good support from a nurse who had a lot of experience in this area (S5).

Facilitation is to find a group that has been working in this area for a long time, that can give you advice as you gradually acquire your own experience (S6).

The interviews revealed that the professionals make every effort to include the family members in all the therapeutic processes. Considering the principles of the Unified Health System - SUS ${ }^{(15)}$, access to this information is considered both a right of patients and a symbol of the foundations of trust and bonding with the team.
Facilitation is when we are really transparent about the treatment, the diagnosis, and the prognosis. So, as things start occurring, the parents can understand why we said something was predictable, that it's not a novelty (S8).

The communication mentioned in this statement is complex because in order to be effective it must consider contexts, cultures, individual values, experiences, interests and expectations ${ }^{(16)}$. In the context of palliative care in paediatric oncology involving systematic hospitalizations, the children and their families create a bond with the health care teams, and this bond facilitates the care they provide.

We create a very close bond with the families and this facilitates our work. You can help them get through this situation, no matter how painful it is. You feel your presence comforts them, and this makes our work a lot easier (S5).

When they are going through a difficult moment, it helps if you have a bond [...] it is easier for you to walk into the room and hug that person, you don't have to say a word because that person will feel what you're trying to say with that hug (S4).

The statements show that presence and concern permeate care relations, and stress that providing palliative care for children transcends the biologic approach to care. The professionals base their praxis on active listening, compassion and affection in order to make this moment more bearable for everyone involved ${ }^{(6)}$. This corroborates the notion that dying patients require unconditional love that is free from any expectations, and professionals require no particular expertise to ensure that patients feel supported ${ }^{(17)}$.

The professionals get emotionally involved with their patients ${ }^{(10)}$, which reveals some ambivalence between feeling and acting. The bond that connects people is the same bond that causes these professionals to suffer when the death of the child is approaching.

The greatest difficulty is to deal with the family, because you end up creating a bond. You take care of that patient and end up having to hide your feelings so you don't grieve with them. Not that you don't suffer, because you do, but at that moment you are there to support the family and not to suffer with the family. You have to show a little more strength (S2).

A child is a child, losing a child is ... I'm not saying it's worse than losing an adult, but it shakes you up a lot more! We 
have to police ourselves to maintain a professional yet human attitude at a very bad time. Because there is no such thing as being accustomed to losing a child, there is no such thing as being prepared to lose a son [...] the problem is finding the words to comfort and reassure that family. We know what to do, but knowing what to say is not always easy, I think it's more difficult (S4).

These statements show that the professionals have mixed feelings, such as justice/injustice, wanting the patient to live/wanting the patient to die, feeling/not feeling, crying/not crying, saying something/saying nothing. These feelings are a reflection of a society that denies suffering through the suppression of grief, and that turns hospitals into hiding places of death and suffering ${ }^{(18)}$. Regardless, in the reality of "childhood cancer, death occurs in everyday care practices and there is no way to hide $\mathrm{it}^{\prime \prime}(19)$. Thus, the team that deals with suffering and loss on a daily basis must learn to reorganize itself in order to move forward.

The phenomenon of death represents more than the end of a biological process; it is the destruction of a being. Having to encounter this possibility on a daily basis is highly distressing ${ }^{(10)}$. In addition to the wide range of emotions, the intense personal reflection and the emotion burden, these professionals must provide care in a short period to the other children in the inpatient unit that are at various stages of oncological treatment, such as diagnosis/staging, chemotherapy, radiation therapy, and long periods of pancytopenia and its life risks. Research shows that the hospital routine causes mental suffering for health care workers ${ }^{(18)}$, as revealed in the following statements:

It's not a very easy unit to work in. It's a lot of work [in every sense]. Look at the complexity of a patient's prescription: chemotherapy, cancer care, analgesia, antiemetic, antimicrobial, antifungal, number of entries, TNP [...]lt requires some preparation! It's very demanding! The chances of something going wrong in the process are huge, from the prescriptions to the administration (S3).

I think we could have more time to talk about patients, as we have 25 beds here, we sometimes run out of time. Sometimes we know we need to talk more about that patient specifically, but have to be objective so we can tend to the other 24 (54)

The statements reveal the complexities involved when providing care for these children, considering the need for extensive technical and scientific knowledge, the emotional burdens that palliative care have on the team and the continuity of care to the other hospitalized children. The professionals try to reassure themselves and make use of their defence mechanisms. However, nothing is capable of mitigating the suffering ${ }^{(10)}$.

\section{Significant lessons learned}

The fact of sharing daily situations inherent to the existential factuality of a child's experience in palliative care and the experience of the family members enables the particular understanding of the current moment. This awareness triggers additional thought on the multiple dimensions of care and reorganizes the focus of attention in the relationship with patients and their families and among members of the same team. The participants mention factors that might qualify such practices and are unanimous in revealing the importance of being able to reflect and further discuss palliative care with the entire multidisciplinary team.

People are too afraid to discuss the issue and talk about their feelings. I think that, working in a unit like this one, we should be able to talk a lot more about our feelings in relation to losing our patients. It would be important to have a specific place for this because when we lose someone, our feelings don't just disappear. I think it would be good for everyone (S7).

These events can make us feel very lonely. Sometimes a child triggers certain feelings in you and in your colleagues and it would be nice to share the experience, the frustrations, fears, anxieties. It would be a lot easier! I think it would improve the group, too (S6).

We have to be able to express our feelings at some point (S3).

The statements reveal the need to create spaces for team members to discuss the personal and professional issues that arise during the work process. However, unlike findings found in literature ${ }^{(18)}$, the professionals of the paediatric oncology unit do not adopt a "don't get involved" attitude in order to simply maintain the idealized professional image. On the contrary, these professionals clearly state that, as in the case of the family members, the child's death leaves them psychologically shaken and they seek personal means to cope with this loss in the best possible way. This finding shows their empathy in relation to their practice and that the genuinely comprehensive care that is being provided from one human being to another in- 
volves all the emotions, joys and frustrations of a complex and challenging approach to care ${ }^{(13)}$.

Their contact with human frailty gradually decreases their power to cope and creates a unbalance between the demands of work and personal needs(18).

I think that people who work with oncology should have more support [...] I know that the hospital provides it, but only if we ask for it and that realization does not always come to us naturally. Lots of people leave because of this, because they aren't strong enough to cope with these situations (S6).

The strict standardization and hierarchy that are present in the hospital institution hinder any meaningful dialogue between the different social actors involved in the process of death and dying ${ }^{(5)}$. The fast-paced routine and the multiple demands of care make it difficult to create this moment of exchange between professionals who feel they are immersed in a systematic and tiring process. However, we believe that these professionals who systematically deal with pain and death must be able to fully elaborate on their emotions so their mourning period can also be processed in a healthy and respectful way.

\section{FINAL CONSIDERATIONS}

This study reveals that professionals understand the difference between palliative action and the proximity of death, and that their concepts and practices do not merely target the care of patients at the end of their lives. The statements show that the multi-professional paediatric oncology team must cope with the singularities of providing palliative care for children and their families on a daily basis.

When they experience moments of intense suffering and emotional and work-related demands, these professionals do not accept the traditional attitude of "don't get involved", and understand that caring for a child in such a complex situation does not merely involve scientific knowledge; it is also an act of kindness and humanity. The results show that although the team members work in different fields, they get involved with the children and their families and build emotional ties that can facilitate care and cause suffering.

It was observed that the professionals seek to exchange knowledge in an attempt to build a foundation of singular care that can help them define their role according to this perspective. The team seeks to include the family in the construction of a singular therapeutic project to guide them through this period of oncological treatment, and to value the family as a protagonist of the child's care.

The findings of this study can be applied to teaching and research insofar as an understanding of the vicissitudes of care for these children and their families acknowledges the need for spaces where health care professionals can share experiences and the lessons they have learned, and ensures that the health team is effectively included in the object of care.

\section{REFERENCES}

1 Faith CF, Hancock LE. Pediatric palliative care: beyond the end of live. Pediatric Nursing. 2012 Aug;38(4):198-203,227.

2 Organização Mundial de Saúde (CH) [Internet]. Cuidados paliativos em pediatría [updated 2013 mar 01; cited 2013 aug 08]. Available at: http://www.who.int/ cancer/palliative/es/index.html

3 Kovács MJ. 0 sofrimento da equipe de saúde no contexto hospitalar: cuidando do cuidador profissional. Mundo Saúde. 2010;34(4):420-9.

4 Stayer D. Pediatric palliative care: a cenceptual analysis for pediatric nursing practice. Journal of Pediatric Nursing. 2012;27:350-6.

5 Borges MS, Mendes N. Representaçōes de profissionais de saúde sobre a morte e o morrer. Rev Bras Enferm. 2012; 65(2): 324-31.

6 Kübler-Ross E. Sobre a morte e o morrer. 4. ed. São Paulo: Martins Fontes, 1969.

7 Issi HB. A experiência existencial de ser mãe de criança portadora de doença crônica com prognóstico reservado: implicaçōes para 0 ensino e a prática da enfermagem. In: Motta MGC, Ribeiro NRR, Coelho DF, organizadoras. Interfaces do cuidado em enfermagem à criança e ao adolescente. Porto Alegre: Expansão; 2012. p.461-82.

8 Minayo MCS. 0 desafio do conhecimento: pesquisa qualitativa em saúde. 12. ed. São Paulo: Editora Hucitec; 2010.

9 Ministério da Saúde (BR). Conselho Nacional de Saúde. Resolução no 466, de 12 de dezembro de 2012. Diretrizes e normas regulamentadoras de pesquisas envolvendo seres humanos. Diário Oficial da União [da] República Federativa do Brasil. 2013 jun 13;150(112 Seção 1):59-62.

10 Silva LC. 0 sofrimento psicológico dos profissionais da saúde na atenção ao paciente com câncer. Psicol Am Lat [Internet]. 2009 jan [cited 2014 jan 15];(16). Available at: http://pepsic.bvsalud.org/scielo.php?script=sci_ arttext\&pid=\$1870-350X2009000100007\&lng=pt\&nrm=iso

11 Pinto CS. Quando o tratamento oncológico passa a ser fútil? do ponto de vista da paliativista. Rev Bras Cancerol. 2008;54(4):393-6.

12 Saunders C. Hospice and palliative care: an interdisciplinary approach. London: Edward Arnold; 1991.

13 Silva AF, Becker HI, Motta MGC. A família da criança oncológica em cuidados paliativos: 0 olhar da equipe de enfermagem. Ciênc Cuid Saúde. 2011;10(4):820-7.

14 Ministério da Saúde (BR), Secretaria de Atenção à Saúde, Núcleo Técnico da Política Nacional de Humanização. Clínica ampliada, equipe de referência e projeto terapêutico singular. 2. ed. Braślia: Ministério da Saúde; 2008.

15 Ministério da Saúde (BR). Lei 8080, de 19 de setembro de 1990. Dispõe sobre as condições para a promoção, proteção e recuperação da saúde, a organização e o funcionamento dos serviços correspondentes e dá outras providências [Internet]. Available at: http://www.planalto.gov.br/ccivil_03/leis/88080.htm 
16 Academia Nacional de Cuidados Paliativos (BR). Manual de cuidados paliativos. Rio de Janeiro: Diagraphic; 2009.

17 Rinpoche S. 0 livro tibetano do viver e do morrer. 7. ed. São Paulo: Talento e Palas; 2002
18 Avellar LZ, Iglesias A, Valverde PF. Sofrimento psíquico em trabalhadores de enfermagem de uma unidade de oncologia. Psicol Estud. 2007;12(3):475-81.

19 Paro D, Paro J, Ferreira DLM. 0 enfermeiro e 0 cuidar em oncologia pediátrica. Arq Ciênc Saúde. 2005;12(3):151-7.

\section{Author's address:}

Adriana Ferreira da Silva

Rua Ângelo Crivellaro, 105/112, Jardim do Salso

91410-080 Porto Alegre - RS

E-mail: enf.adriana@live.com
Received: 07.04.2014

Approved: 10.03.2015 